\title{
Probiotic Properties of Lactobacillus strains Isolated from Kimchi
}

\author{
Hye Jung Choi ${ }^{1}$, Bo Ram $\mathrm{Lim}^{1}$, Dong Wan Kim², Gi-Seok Kwon ${ }^{3}$ and Woo Hong Joo ${ }^{1, *}$ \\ ${ }^{1}$ Department of Biology, Changwon National University, Changwon 641-240, Korea \\ ${ }^{2}$ Department of Microbiology, Changwon National University, Changwon 641-240, Korea \\ ${ }^{3}$ School of Bioresource Science, Andong National University, Andong 760-749, Korea
}

Received September 24, 2014 /Revised November 24, 2014 /Accepted November 27, 2014

\begin{abstract}
The objective of this study was to evaluate the safety and functional properties of four potential probiotic strains isolated from Kimchi, traditional Korean fermented vegetables. Based on being higher tolerance to bile salts and showing higher acid resistance or hydrophobic properties, one Lactobacillus arizonensis strain (BCNU 9032) and three L. brevis strains (BCNU 9037, BCNU 9098 and BCNU 9101) were selected in the screening experiment. All strains can survived up to $99 \%$ after $3 \mathrm{~h}$ culture in $\mathrm{pH}$ 2.5 and resistant to $1 \%$ bile salts. These strains also showed good antimicrobial activities against a number of food borne pathogens, especially against Escherichia coli and Shigella sonnei. The ability to lower cholesterol levels of L. arizonensis BCNU 9032 and L. brevis 9037 were demonstrated by bile salt hydrolytic activity and cholesterol assimilation tests. Moreover, L. brevis BCNU 9098 and BCNU 9101 showed higher adherence to Caco-2 cells (12.76 and 11.86\%, respectively) than Lactobacillus rhamnosus GG, a commercial probiotic strain used worldwide. The results suggest that these strains could be used as probiotics.
\end{abstract}

Key words : Adhesion abilities, cholesterol assimilation, Lactobacillus strains, potential probiotics

\section{서 론}

한국의 대표적인 전통발효 식품으로 자리매김한 김치는 최 근 국외에서도 건강식품으로서 그 기능성이 인정되어 세계 5대 건강식품 중에 하나로 꼽혀 미국 health magazine에 소개 된 바가 있다(http://www.health.com/world's healthiest foods Kimchi-Korea, Feb 1, 2008). 배추, 양배추 무, 무청 및 파 등 소금에 절인 채소에 마늘, 고춧가루, 생강, 소금 및 젓갈 등을 양념으로 첨가하여 발효시킨 김치는 항산화, 면역자극 활성, 항돌연변이[5], 항종양[23], 항혈전, 항노화[13], 항동맥경 화[14] 및 항균활성[22] 등 다양한 기능을 가지고 있음이 보고 되면서 관심이 고조되고 있다. 이러한 기능성은 각종 비타민, 무기질, 식이섬유 및 phytochemical 등 원재료 자체의 생리활 성과 젖산균에 의한 발효산물 그리고 상존하는 미생물 군집의 활성에서 기여되고 있는 것으로 보고되고 있다[15]. Leuconostoc (Leuc.), Lactobacillus, Weissella, Pediococcus 그리고 Lactococcus 속 종 등을 포함하고 있는 lactic acid bacteria (LAB)는 김치 발효에서 맛과 질뿐만 아니라 인체 건강에도 중요한 역할을 담당하고 있으며, 최근에는 김치 발효 표준화를 위해 Leuc.

\section{*Corresponding author}

Tel : +82-55-213-3453, Fax : +82-55-213-3459

E-mail : whjoo@changwon.ac.kr

This is an Open-Access article distributed under the terms of the Creative Commons Attribution Non-Commercial License (http://creativecommons.org/licenses/by-nc/3.0) which permits unrestricted non-commercial use, distribution, and reproduction in any medium, provided the original work is properly cited. mesenteroides, Leuc. citreum 및 L. plantarum을 starter 균주로 적용한 제품이 다수 출시되고 있다. 일반적으로 $\mathrm{LAB}$ 는 미국 과 유럽의 안전성 평가기준인 Generally Recongnized as Safe (GRAS)와 Qualified Presumption of Safety (QPS)에 해당되는 균주로 인체위해성이 없는 것으로 간주되고 있지만, Lactobacilli와 bifidobacteria는 매우 드물게 인체에 기회감염을 일으 켜 감염성 심내막염 또는 균혈증 등의 감염병변[4]에서 발견되 기도 하여 프로바이오틱스 연구에 있어서 기본적으로 안전성 이 확보된 균주의 개발이 절실히 필요한 실정이다.

Lactobacillus는 대표적인 김치 유산균 가운데 하나로 L. acidophilus LA1, L. casei Shirota, L. plantarum LP01, L. rhamnosus GG 및 L. fermentum RC14 등은 현재 프로바이오틱스로서 상 업적으로 이용되고 있다[9]. 특히 Lactobacillus는 장내균총의 안정화, 과민성대장증후군 및 유당불내증 개선효과가 뛰어나 며 $[1,27]$, 유산균 및 장내 유해균에 의해 생성되어 인체에 위해 를 줄 수 있는 발효식품에 존재하는 biogenic amine을 생산하 지 않거나 분해하는 등 인체 건강에 도움을 주는 것으로 보고 되고 있다.

따라서 본 연구에서는 안전성 확보 및 향상된 기능성을 가 진 잠재적인 프로바이오틱스를 분리하기 위해 일반가정에서 담근 다양한 김치로부터 Lactobacillus sp.을 분리하였으며, 항 생제 내성, 용혈성 및 유해효소 생산 및 기본적인 안전성, 내산 성 및 내담즙산 등의 안정성과 식중독 원인균에 대한 항균활 성, bile salt hydrolase 활성, 콜레스테롤 동화작용 및 Caco-2 cell을 이용한 장 상피세포 부착능 등의 기능성 검증을 통해 다기능성 프로바이오틱스 균주를 개발하고자 본 연구를 수행 
하였다.

\section{재료 및 방법}

\section{프로바이오틱스의 분리 및 동정}

일반가정에서 담근 배추김치, 열무김치, 물 김치, 총각김치 5 종의 다양한 김치를 수집하여 프로바이오틱스 균주를 분리 하는데 이용하였다. $1 \mathrm{ml}$ 의 시료를 PBS buffer $(\mathrm{pH}$ 6)에 10 배 희석하여 이를 nutrient agar $(\mathrm{NA}), 0.5 \%(\mathrm{w} / \mathrm{v}) \mathrm{CaCO}_{3}$ 을 첨가 한 lactobacilli de Man-Rogosa-Sharpe (MRS) agar 및 R2A 배지에 접종하여 $37^{\circ} \mathrm{C}$ 에서 2-4일 배양한 후 균주를 순수분리 하였다. 순수분리된 균주는 PBS (pH 2.0)에 현탁하고 2시간 정치 배양 후, 내산성이 뛰어난 균주 20 colonies를 1차 선별하 였고, Bergey's Manual of determinative bacteriology를 참고 하여 생리·생화학적 특성을 조사하였다[24]. 또한 $16 \mathrm{~S}$ 리보솜 RNA 염기서열을 분석한 뒤 Bioedit (USA), Clustal X2.0 (CLC bio, Denmark) 그리고 Mega 4 를 이용하여 계통학적인 위치를 확인하였다[21].

\section{용혈성 및 안전성 검사}

대상균주를 면양혈액한천배지(Asan Pharmacy Co., Seoul, Korea)에 접종하여 $37^{\circ} \mathrm{C}$ 에서 48 시간 배양한 뒤, 균주의 용혈 성 여부를 확인하였고, Scientific Committee for Animal Nutrition (SCAN, 2002)와 European Food Safety Authority (EFSA, 2008) 지침을 참고하여 ampicillin, chloramphenicol, erythromycin, gentamicin, streptomycin 및 tetracycline에 대 한 항생제 감수성을 조사하였다 [8, 20]. 또한 $\beta$-glucoronidase, tryptophanse 및 urease와 같은 효소 생성여부를 대조군으로 Escherichia coli ATCC 10798과 L. acidophilus ATCC 4356을 사 용하여 조사하였다.

\section{내산성 및 내담즙산 활성조사}

MRS 배지에 전배양한 실험균주 $1 \mathrm{ml}$ 을 원심분리하여 $\left(8,000 \times \mathrm{g}, 15 \mathrm{~min}, 4^{\circ} \mathrm{C}\right), \mathrm{PBS}(\mathrm{pH}$ 6.0)로 두 번 세척한 뒤 버퍼 및 배지 $1 \mathrm{ml}$ 에 현탁하였다. 내산성 조사는 $9 \mathrm{ml}$ 의 PBS $\left(\mathrm{pH}\right.$ 2.5)에 접종하여 $37^{\circ} \mathrm{C}$ 에서 3 시간 동안 진탕배양한 뒤 0 시 간과 3 시간 후의 생균수를 측정하였고, 담즙산염에 대한 저항 성은 $0.3 \%, 0.6 \%$ 및 $1 \%$ 의 bile salt가 각각 첨가된 $9 \mathrm{ml} \mathrm{MRS}$ broth에서 0 시간과 24 시간 배양 후의 생균수를 비교함으로써 생존률을 조사하였다.

\section{항균활성 조사}

6종의 식중독 원인균(Bacillus cereus ATCC 14579, Listeria monocytogenes ATCC 15313, Staphylococcus aureus ATCC 6538, E. coli ATCC 10798, Shigella sonnei ATCC 25931 및 Salmonella typhimurium ATCC 14028)에 대한 항균활성은 agar diffusion
법으로 조사하였다[18]. MRS 배지에서 전배양한 균주를 원심 분리하여 $\left(8,000 \times \mathrm{g}, 15 \mathrm{~min}, 4^{\circ} \mathrm{C}\right)$ 배양 상등액을 $\mathrm{pH}$ 6.5로 중화시킨 뒤, 여과하여 $(0.22 \mu \mathrm{m}$ membrane; Millipore) 항균력 측정을 위한 시료로 사용하였다.

\section{Bile salt hydrolase (BSH) 활성 및 콜레스테롤 동화작용}

$\mathrm{BSH}$ 활성은 $0.5 \%$ taurodeoxycholic acid와 $0.37 \mathrm{~g} / \mathrm{l} \mathrm{CaCl}_{2}$ 이 함유된 MRS agar에 실험균주 배양액을 $10 \mu \mathrm{l}$ 점적하여, $37^{\circ} \mathrm{C}$ 에서 48 시간 배양한 뒤 흰색환의 생성여부로 판단하였다. 또한 콜레스테롤 동화능의 측정은 $0.5 \%(\mathrm{w} / \mathrm{v}) \mathrm{TDCA}$ 와 0.1 $\mathrm{g} / 1$ 수용성 cholesterol을 첨가한 MRS broth에 실험균주 $\left(10^{8}\right.$ cells $/ \mathrm{ml}$ 를 접종하여 $37^{\circ} \mathrm{C}$ 에서 24 시간 배양하였다. 배양액을 원심분리한 뒤 $\left(10,000 \times \mathrm{g}, 10 \mathrm{~min}, 4^{\circ} \mathrm{C}\right)$ 배양 상등액에 $95 \%$ 에탄올과 $0.5 \mathrm{M}$ potassium hydroxide을 첨가하여 $60^{\circ} \mathrm{C}$ 에서 반응시켰다. 10분 후 hexane을 첨가하여 실온에서 추가 반응 시킨 후 용매층을 회수하여 액체질소로 증발시키고 o-phthaladehyde 용액과 $\mathrm{H}_{2} \mathrm{SO}_{4}$ 를 가하고 10 분간 반응시킨 후 흡광도 $\left(\mathrm{OD}_{550}\right)$ 를 측정하여 잔존 콜레스테롤 양을 정량적으로 측정하 였다[2, 17].

\section{세포표면 소수성}

균주의 세포표면 소수성은 탄화수소로서 $n$-hexadecane과 chloroform에 부착하는 정도를 측정하였다[7]. 전배양한 균주 는 원심분리 후, 균체를 모아 PBS (pH 6.0)로 두 번 세척하였고 $10^{5}$ cells $/ \mathrm{ml}$ 농도로 현탁한 뒤 $n$-hexadecane 또는 chloroform 을 $1: 1$ 비율로 첨가하였다. 2 분간 혼합하고 실온에서 30 분간 정치배양을 한 뒤에 배지층의 흡광도 $\left(\mathrm{OD}_{580}\right)$ 를 측정하여 초기 흡광도와 비교함으로써 세포표면의 소수성 정도를 확인하였 다.

\section{Caco-2 cell에 대한 부착능 측정}

실험에 사용한 colon cancer cells (Caco-2 cells, KCLS)은 $10 \%$ FBS (fetal bovine serum), 100 units $/ \mathrm{ml}$ penicillin 과 100 $\mu \mathrm{g} / \mathrm{ml}$ streptomycin이 첨가된 Dulvecco's Modified Eagle Media (DMEM, Gibco) 배지를 사용하여, $37^{\circ} \mathrm{C}, 5 \% \mathrm{CO}_{2}$ 조건 에서 배양하였다. 실험균주를 MRS 배지에서 18 시간 배양한 후, 원심분리 $\left(3,000 \mathrm{rpm}, 20 \mathrm{~min}, 4^{\circ} \mathrm{C}\right)$ 로 균체를 회수하여 PBS (pH 7.2)로 2회 세척한 후에 serum free DMEM에 $10^{8} \mathrm{CFU} / \mathrm{ml}$ 농도로 현탁하고 caco-2 세포가 $10^{6}$ cells/well 농도로 접종되 어 있는 24-well plates에 $0.5 \mathrm{ml} /$ well를 첨가하였다. $37^{\circ} \mathrm{C}, 5 \%$ $\mathrm{CO}_{2}$ 조건하에서 2시간 배양한 후에 $1 \mathrm{ml}$ 의 $0.1 \%$ tritonX-100 을 첨가하여 5 분간 고정시키고 $\mathrm{PBS}$ 로 세척을 통해 부착되지 않은 세포를 제거한 뒤 생균수를 측정함으로써 대조구와 비교 하여 Caco-2 cell에 대한 부착능을 측정하였다[25]. 


\section{결과 및 고찰}

\section{Lactobacillus 균주들의 선발 및 동정}

1 차 선별된 50 여개의 콜로니는 형태 및 생리학적 특성조사 를 통해 그람양성의 장간균으로 낮은 $\mathrm{pH}$ 범위에서 생존가능 한 4종의 균주를 선별하였고(Table 1), $16 \mathrm{~S}$ 리보솜 RNA 염기 서열 분석을 통해 최종적으로 L. arizonensis DSM $13273^{\mathrm{T}}$ (GenBank accession number: AJ965487)와 근연종인 BCNU 9032와 L. brevis DSM $20054^{\mathrm{T}}$ (GenBank accession number: $\mathrm{M} 58810)$ 의 근연종인 $\mathrm{BCNU}$ 9037, $\mathrm{BCNU} 9098$ 그리고 $\mathrm{BCNU}$ 9101 균주를 선발하였다.

\section{안전성 조사를 위한 in vitro 시험}

프로바이오틱스로서 섭취시 인체에 유해성을 나타낼 수 있 는 여러가지 인자를 조사한 결과, 4 종의 균주는 sheep blood가 포함된 한천배지에서 용혈현상이 없는 $\gamma$-형으로 나타났고, 장 내세균이 생산하는 유해효소인 $\beta$-glucoronidase, tryptophanase 및 urease를 분비하지 않는 것으로 조사되었다(Table 2).
섭취하는 음식과 장내세균은 밀접한 관계가 있으며, 유해하지 않은 식품도 대사과정에서 장내세균이 생산하는 유해효소( $\beta$ glucoronidase와 tryptophanase 등)로 인해 발암물질로 전환 될 수 있다는 연구가 보고된 바 있다[12].

항생제 감수성 조사에서 BCNU 9032가 streptomycin에 대 해 $\mathrm{EFSA}$ 와 $\mathrm{SCAN}$ 의 기준보다 높은 저항성을 가지고 있었으 며, 4 종의 균주가 gentamicin에 대해 SCAN 기준에 비해 저항 성이 있는 것으로 나타났다(Table 3). 그러나 Danielsen \& Wind는 많은 Lactobacillus 속 균주가 aminoglycoside계 항생 제에 저항성이 높은 것으로 보고하였으며[6], 김치에서 분리된 다수의 L. sakei와 L. plantarum이 선발균주와 비슷한 경향의 항생제 감수성을 가진 것으로 보고되었다[15]. 그러므로 선발 된 균주 모두 안전한 것으로 판단된다.

\section{$\mathrm{pH}$ 및 담즙산염에 대한 안정성}

섭취 시 균체가 장내에 도달하여 기능성을 나타내기 위해서 는 낮은 $\mathrm{pH}$ 와 담즙산에 대한 내성 능력이 필수적이다. 선발된 균주의 $\mathrm{pH}$ 에 대한 내성은 $\mathrm{pH} 2.5$ 에서 초기균수와 3 시간 후의

Table 1. Physiological properties of selected Lactobacillus strains

\begin{tabular}{|c|c|c|c|c|}
\hline Characteristics & BCNU 9032 & BCNU 9037 & BCNU 9098 & BCNU 9101 \\
\hline Gram's reaction & $++^{1)}$ & + & + & + \\
\hline Optimum growth temperature $\left({ }^{\circ} \mathrm{C}\right)$ & 37 & 37 & 37 & 37 \\
\hline Growth $\mathrm{pH}$ & $2.5-9.0$ & $2-9.0$ & $2-9.0$ & $2.5-9.0$ \\
\hline Growth $\mathrm{NaCl}(\%)$ & $3-5$ & $3-5$ & $3-5$ & $3-5$ \\
\hline \multicolumn{5}{|l|}{ Assimilation of carbohydrate } \\
\hline Arabinose & - & - & - & - \\
\hline Cellobiose & - & - & - & - \\
\hline Fructose & - & - & - & - \\
\hline Galactose & - & - & - & - \\
\hline Glucose & + & + & + & + \\
\hline Lactose & + & + & + & + \\
\hline Mannose & + & + & + & + \\
\hline Mannitol & + & + & + & + \\
\hline Raffinose & + & + & + & + \\
\hline Sucrose & + & + & + & + \\
\hline Xylose & - & + & + & + \\
\hline
\end{tabular}

${ }^{1)}+$; Positive, - ; negative

Table 2. Haemolytic activity and production of enzyme in LAB strains

\begin{tabular}{|c|c|c|c|c|c|c|}
\hline Characteristics & BCNU 9032 & BCNU 9037 & BCNU 9098 & BCNU 9101 & E. c & L. $a$ \\
\hline Heamolysis & $\gamma$-hemolysis & $\gamma$-hemolysis & $\gamma$-hemolysis & $\gamma$-hemolysis & - & $\gamma$-hemolysis \\
\hline Gelatinase & -1) & - & - & - & - & - \\
\hline$\beta$-glucosidase & - & - & - & - & + & - \\
\hline$\beta$-glucuronidase & - & - & - & - & + & - \\
\hline Tryptophanase & - & - & - & - & + & - \\
\hline Urease & - & - & - & - & - & - \\
\hline
\end{tabular}

${ }^{1)}$ E.c: Escherichia coli ATCC 10798; L.a: Latobacillus. acidophilus ATCC 4356

${ }^{2)}+$ : positive, - : negative 
Table 3. Minimum inhibitoy concentration (MIC) $\mu \mathrm{g} / \mathrm{ml}$ of antibiotics to Lactobacillus strains

\begin{tabular}{lcccccc}
\hline & $\mathrm{Em}^{1)}$ & $\mathrm{Gm}$ & $\mathrm{Am}$ & $\mathrm{Te}$ & $\mathrm{Ch}$ & $\mathrm{Sm}$ \\
\hline BCNU 9032 & $<0.25$ & 16 & $<0.25$ & 1 & 1 & $>64$ \\
BCNU 9037 & $<0.25$ & 4 & $<0.25$ & 4 & 1 & 32 \\
BCNU 9098 & $<0.25$ & 4 & $<0.25$ & 2 & 1 & 16 \\
BCNU 9101 & $<0.25$ & 2 & $<0.25$ & 2 & 1 & 16 \\
SCAN & 4 & 1 & 2 & 16 & 16 & 16 \\
Danielsen \& Wind & 4 & 128 & 4 & 4 & 16 & $>256$ \\
EFSA & 1 & 16 & 4 & 8 & 4 & 64
\end{tabular}

${ }^{1)}$ Em: erythromycin; Gm: gentamicin; Am: ampicillin; Te: tetracycline; Ch: chloramphenicol; Sm: streptomycin.

Table 4. Acid resistance of Lactobacillus sp. strains

\begin{tabular}{lccr}
\hline & $\begin{array}{c}\text { Initial mean counts } \\
(\log \text { CFU/ml })\end{array}$ & $\begin{array}{c}\text { Survival after } \\
3 \mathrm{hr} \text { at } \mathrm{pH} 2.5\end{array}$ & $\begin{array}{c}\text { Survival } \\
\text { rate }(\%)\end{array}$ \\
\hline BCNU 9032 & $8.81 \pm 0.01$ & $8.82 \pm 0.01$ & 100.11 \\
BCNU 9037 & $8.84 \pm 0.01$ & $8.83 \pm 0.01$ & 99.89 \\
BCNU 9098 & $8.97 \pm 0.00$ & $8.94 \pm 0.11$ & 99.67 \\
BCNU 9101 & $8.89 \pm 0.01$ & $8.93 \pm 0.00$ & 100.45 \\
\hline
\end{tabular}

생존력을 비교함으로써 확인하였다(Table 4). BCNU 9032와 $\mathrm{BCNU}$ 9101은 낮은 산성 환경에 전혀 영향을 받지 않았으며, $\mathrm{BCNU}$ 9037과 BCNU 9098도 99.6\% 이상 생존률을 보임으로 써 산에 대한 안정성은 매우 높은 것으로 확인되었다. 또한 4 종의 선발균주는 $1 \%$ 의 고농도의 담즙산에서 $99-100 \%$ 생존 률을 보임으로써 담즙산에 대한 영향을 받지 않는 것으로 나 타났으며(Table 5), 이는 김치에서 분리한 10 여종의 L. sakei가 $3.25 \%$ oxgall에서 생존률이 $10 \%$ 내외인 것으로 보고된 바 있 으나[15] 이에 비해 4 개의 선발균주가 본 실험을 통해 담즙산
에 대한 뛰어난 안정성을 보유한 균주임이 확인되었다.

\section{항균활성}

Paper disc법에 따라 $8 \mathrm{~mm}$ 의 disc에 $50 \mu \mathrm{l}$ 의 균 배양 상등액 을 접종하여 그람양성 세균 3종과 그람음성 세균 3종의 식중 독 원인균에 대해 항균활성을 조사하였다. BCNU 9032와 $\mathrm{BCNU}$ 9037의 배양 상등액은 대체로 넓은 항균스펙트럼을 가 지고 있는 것으로 나타났다(Table 6). 특히 E. coli에 대해 저해 환 $19 \mathrm{~mm}$ 의 높은 항균 활성을 보였고, List. monocytogenes와 S. sonnei에 대해서도 우수한 항균 활성을 가지고 있음이 확인 되었다. BCNU 9098과 BCNU 9101의 배양 상등액 또한 E. coli 에 대한 항균 활성이 가장 높은 것으로 나타남으로써 4 종의 균주가 생산하는 이차대사산물들이 전반적으로 그람음성 세 균에 대한 높은 항균 활성을 나타내는 것으로 조사되었다. 기 존의 연구된 Lactobacillus sp. 균주가 대부분 E. coli에 대한 항 균 활성이 없거나 S. aureus에 비해 상대적으로 낮은 항균 활성 을 가진 것과 비교하여 다소 차이가 있었으며[11, 17], 실험균

Table 5. Bile resistance of Lactobacillus sp. strains

\begin{tabular}{lccccccr}
\hline & $\begin{array}{c}\text { Control } \\
(\log \text { CFU } / \mathrm{ml})\end{array}$ & $0.3 \%$ & $\begin{array}{c}\text { Survival rate } \\
(\%)\end{array}$ & $0.6 \%$ & $\begin{array}{c}\text { Survival rate } \\
(\%)\end{array}$ & $\begin{array}{r}\text { Survival rate } \\
(\%)\end{array}$ \\
\hline BCNU 9032 & $7.87 \pm 0.01$ & $7.87 \pm 0.02$ & 100.01 & $7.85 \pm 0.01$ & 99.72 & $7.78 \pm 0.01$ & 98.87 \\
BCNU 9037 & $7.89 \pm 0.02$ & $7.88 \pm 0.02$ & 99.97 & $7.89 \pm 0.03$ & 100 & $7.86 \pm 0.01$ & 99.72 \\
BCNU 9098 & $7.97 \pm 0.00$ & $8.15 \pm 0.00$ & 102.30 & $8.07 \pm 0.01$ & 101.29 & $8.01 \pm 0.01$ & 100.60 \\
BCNU 9101 & $7.75 \pm 0.01$ & $7.97 \pm 0.01$ & 102.77 & $7.90 \pm 0.01$ & 101.91 & $7.76 \pm 0.02$ & 100.13 \\
\hline
\end{tabular}

Survival of LAB strains was compared by plate counting after exposure with bile salt $0.3 \%, 0.6 \%, 1 \%$ in MRS broth for 0 and $24 \mathrm{hr}$.

Table 6. Antimicrobial activities of Lactobacillus sp. strains against food-borne pathogens

\begin{tabular}{ccccccc}
\hline & B. $c^{1)}$ & L. $m$ & S. $a$ & E. $c$ & S. $s$ & S. $t$ \\
\hline BCNU 9032 & $11.5 \pm 0.5^{2)}$ & $16.5 \pm 2.1$ & - & 19 & $16 \pm 1.4$ & $13.5 \pm 0.7$ \\
BCNU 9037 & $12 \pm 1.0$ & $15.5 \pm 3.5$ & - & $19 \pm 1.0$ & $15.5 \pm 0.7$ & $12.5 \pm 0.7$ \\
BCNU 9098 & - & - & $11.5 \pm 0.5$ & $16.5 \pm 0.5$ & $11 \pm 1.4$ & - \\
BCNU 9101 & $11 \pm 1.0$ & - & $15.5 \pm 2.1$ & $17 \pm 1.0$ & 11 & - \\
\hline
\end{tabular}

${ }^{1)}$ B.c: Bacillus cereus; L.m: Listeria monocytogenes; S.a: Staphylococcus aureus; E.c: Escherichia coli; S.s: Shigella sonnei; S.t: Salmonella typhimurium.

${ }^{2)}$ Each value represents a diameter of clear zone $(\mathrm{mm}$; mean $\pm \mathrm{SD}, \mathrm{n}=3$ ).

3) - ; negative 
Table 7. Cholesterol-related activities and hydrophobicity of selected probiotic Lactobacillus sp. strains

\begin{tabular}{ccccc}
\hline \multirow{2}{*}{ Strains } & \multirow{2}{*}{ BSH activity } & Cholesterol assimilation (\%) & \multicolumn{2}{c}{ Hydrophobicity (\%) } \\
\cline { 4 - 5 } & & & n-hexadecane & chloroform \\
\hline BCNU 9032 & $++^{1)}$ & $54.28 \pm 5.31$ & $56.70 \pm 2.08$ & $63.22 \pm 0.52$ \\
BCNU 9037 & + & $50.90 \pm 8.66$ & $99.65 \pm 0.23$ & $96.28 \pm 1.68$ \\
BCNU 9098 & - & $17.81 \pm 1.74$ & $92.53 \pm 1.31$ & $98.33 \pm 2.70$ \\
BCNU 9101 & - & $7.93 \pm 3.54$ & $97.83 \pm 0.40$ & $94.52 \pm 1.46$ \\
\hline
\end{tabular}

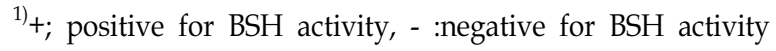

이 대부분의 식중독 원인균인 그람음성 세균에 대해 활성이 매우 우수함을 확인할 수 있었다.

\section{콜레스테롤 저하 효능과 소수성}

$\mathrm{BSH}$ 활성은 $\mathrm{BSH}$ agar 배지에서 흰색 침전환이 생성되는 것으로 확인할 수 있었으며, $\mathrm{BCNU}$ 9032와 $\mathrm{BCNU}$ 9037은 모 두 $\mathrm{BSH}$ 활성을 가지고 있는 효소를 분비하는 것으로 확인되 었다(Table 7). 그리고 TDCA와 수용성 cholesterol을 배지에 첨가하고 배양하여 잔존 콜레스테롤양을 측정하는 동화능 실 험에서도 BCNU 9032와 BCNU 9037은 50\% 이상의 활성을 보임으로써 콜레스테롤 저하 효능이 뛰어남을 확인할 수 있었 다. 김치에서 분리한 L. sakei는 40-60\%, L. plantarum NR74는 $47.8 \%$ 그리고 상업 균주인 L. rhamnosus GG가 $48 \%$ 의 콜레스 테롤 저하효능이 있음이 보고되어 있다[15]. 그러므로 실험에 사용한 균주에서 이들 균주보다 다소 뛰어난 콜레스테롤 저하 효능이 확인되었다.

세포표면의 소수성은 병원성 세균과의 부착 및 응집현상, 숙주세포의 방어 등 다양한 현상들과 연관되어 있으며 $[3,10]$, 본 연구에서는 미생물의 탄화수소에 대한 부착능을 측정함으 로써 소수성 정도를 측정하였다. BCNU 9037은 $n$-hexadecane 첨가시 $99.6 \%$ 이상의 높은 부착능을 보였으며, $\mathrm{BCNU} 9098$ 과 $\mathrm{BCNU} 9101$ 도 $90 \%$ 이상의 부착능을 가짐으로써 세포표면의 소수성이 매우 높은 것으로 나타났다(Table 7). 발효 코코아에 서 분리한 L. brevis $\mathrm{FFC199}$ 와 SAU105는 xylene 첨가시 각각 $0.26 \%, 60.98 \%$ 의 부착능을 보였으며, L. rhamnosus GG는

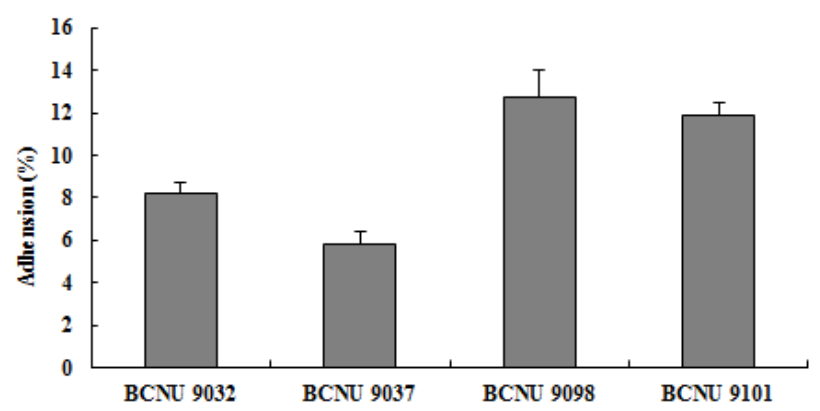

Fig. 1. Adhesion ability of Lactobacillus sp. strains to Caco-2 cell. The adherence percentage of LAB strains to Caco-2 cells was calculated by comparing the plate counts between initial and adhered bacteria. Each value represents mean $\pm S D, n=3$. $n$-hexadecane 처리시 $100 \%$ 의 부착능을 가진 것으로 나타남으 로써 콜레스테롤 동화능과 세포표면 소수성면에서 $\mathrm{BCNU}$ 9037과 유사함을 확인할 수 있었다.

\section{Caco-2 cell에 대한 부착능}

프로바이오틱스 균주의 장관 상피세포 유래의 Caco-2 cell 에 대한 부착능력은 $\mathrm{BCNU}$ 9098과 $\mathrm{BCNU}$ 9101이 각각 12.8\%, $11.9 \%$ 로 BCNU 9032의 8.2\%, BCNU 9037의 5.8\%보다 상대적 으로 높게 나타났다(Fig. 1). 세포표면 특성은 장내세포와의 응집력 및 부착능과 연관성이 높은 것으로 알려져 있으며[26], 소수성이 높은 $\mathrm{BCNU}$ 9098과 $\mathrm{BCNU}$ 9101이 상대적으로 Caco-2 cell에 대한 부착능이 높은 것으로 본 실험에서도 확인 되었다. 낙농제품에서 분리한 29종의 Lactobacillus sp. 균주의 Caco-2 부착능은 $0.1-25.5 \%$ 범위로 평균 $5 \%$ 내외인 것으로 보고되고 있으며[16], L. plantarum SAU96, L. brevis FFC199 및 상업 균주인 L. rhamnosus GG의 Caco-2 cell 부착능은 각각 $1.8 \%, 0.9 \%$ 그리고 $1.5 \%$ 로 보고되고 있으므로[19] 결과를 참고로 할 때 이들 균주들은 인체장관의 상피세포에의 부착능력도 우수 할 것으로 사료되며 차후에 이를 실험으로 증명할 필요가 있다.

김치로부터 분리한 4 종의 Lactobacillus sp.는 GRAS 균주로 식품첨가물로써 사용가능한 안전한 균주이며, 본 연구에서도 인체에 유해할 수 있는 효소 생산을 하지 않는 것으로 확인되 었다. 프로바이오틱스로서 기본적인 산성과 담즙산에 대해 우 수한 안정성을 보였으며, BCNU 9032와 9037은 E. coli와 S. sonnei에 대해 특히 뛰어난 항균활성을 가진 것으로 나타났다. 또한 BCNU 9032와 9037은 BSH 활성 및 콜레스테롤 수준을 $50 \%$ 이상 감소시켰으며, 소수성 실험을 통해 섭취시 장내 부 착능이 우수할 것으로 판단되어 프로바이오틱스로서 섭취시 장내환경 개선에 크게 도움을 줄 수 있을 것으로 사료된다.

\section{감사의 글}

이 논문은 2013 2014년도 창원대학교 연구비에 의하여 연 구되었음.

\section{References}

1. Alander, M., Satokari, R., Korpela, R., Saxelin, M., Vilppo- 
nen-Salmela, T., Mattila-Sandholm, T. and Von Wright, A. 1999. Persistence of colonization of human colonic mucosa by a probiotic strain, Lactobacillus rhamnosus GG, after oral consumption. Appl Environ Microbiol 65, 351-354.

2. Allain, C. C., Poon, L. S., Chen, C. G., Richmond, W. and Paul, C. 1974. Enzymatic determination of total serum cholesterol. Clin Chem 20, 470-475.

3. Bar-Ness, R., Avrabamy, N., Matsuyama, T. and Rosenberg, M. 1988. Increased cell surface hydrophobicity of a Serraia marcescens NS 38 mutant lacking wetting activity. J Bacteriol 170, 4361-4364.

4. Borriello, S. P., Hammes, W. P., Holzapfel, W., Marteau, P., Schrezenmeir, J., Vaara, M. and Valtonen, V. 2003. Safety of probiotics that contain lactobacilli or bifidobacteria. Clin Infect Dis 36, 775-780.

5. Cho, E. J., Rhee, S. H., Lee, S. M. and Park, K. Y. 1997. In vitro antimutagenic and anticancer effects of kimchi fractions. J Korean Ass Cancer Prev 2, 113-121.

6. Danielsen, M. and Wind, A. A. 2003. Susceptibility of Lactobacillus spp. to antimicrobial agents. Int $J$ Food Microbiol 82, 1-11.

7. Doyle, R. J. and Rosenberg. M. 1995. Measurement of microbial adhesion to hydrophobic substrates. Methods Enzymol 253, 542-550.

8. EFSA. (2008). Technical guidance prepared by the panel on additives and products or substances in animal feed (FEEDAP) on the update of the criteria used in the assessment of bacterial resistance to antibiotics of human and veterinary importance. EFSA J 732, 1-15.

9. Giraffa, G., Chanishvili, N. and Widyastuti, Y. 2010. Importance of lactobacilli in food and feed biotechnology. Res Microbiol 161, 480-487.

10. Hazen, K. C., Lay, J. G., Hazen, B. W., Fu, R. C. and Murthy, S. 1990. Partial biochemical charaterization of cell surface hydrophobicity and hydrophilicity of Candida albicans. Infect Immun 58, 3469-3476.

11. Bang, J. H., Shin, H, J., Choi, H. J., Kim, D. W., Ahn, C. S., Jeong ,Y. K. and Joo, W. H. 2012. Probiotic potential of Lactobacillus isolates. J Life Sci 22, 251-258.

12. Keisuke, T., Emiko, H., Nakagawa, G. U. and Masuo, S. 1996. Long-term effect of dietary fiber and fat intake on Japanese colon cancer mortality. Biosc Microflora 15, 77-74.

13. Kim, B. K., Park, K. Y., Kim, H. Y., Ahn, S. C. and Cho, E. J. 2011. Anti-aging effects and mechanisms of Kimchi during fermentation under stress-induced premature senescence cellular system. Food Sci Biotechnol 20, 643-649.

14. Kim, H. J., Kwon, M. J., Seo, J. M., Kim, J. K., Song, S. H., Suh, H. S. and Song, Y. O. 2004. The effect of 3-(4'-hydroxyl-3',5'-dimethoxyphenyl) propionic acid in Chinese cabbage kimchi on lowering hypercholesterolemia. J Korean Soc Food Sci Nutr 33, 52-58.

15. Lee, H. J., Yoon, H. S., Ji, Y. S., Kim, H, N., Park, H. J.,
Lee, J. E., Shin, H. K. and Holzapfel, W. H. 2011. Functional properties of Lactobacillus strains isolated from kimchi. Int J Food Microbiol 145, 155-161.

16. Maragkoudakisa, P. A., Zoumpopouloua, G., Miarisa, C., Kalantzopoulosa, G., Potb, B. and Tsakalidoua, E. 2006. Probiotic potential of Lactobacillus strains isolated from dairy droducts. Int Dairy J 16, 189-199.

17. Mathara, J. M., Schillinger, U., Guigas, C., Franz, C. M. A. P., Kutima, P. M., Mbugua, S., Shin, H. K. and Holzapfel, W. H. 2008. Functional characteristics of Lactobacillus spp. Form traditional Maasai fermented milk products in Kenya. Int J Food Microbiol 126, 57-64.

18. Mishra, V. and Prasad, D. N. 2005. Application of in vitro methods for selection of Lactobacillus casei strains as potential probiotics. Int J Food Microbiol 103, 109-115.

19. Ramos, C. L., Thorsen, L., Schwan, R. F. and Jespersen, L. 2013. Strain-specific probiotics properties of Lactobacillus fermentum, Lactobacillus plantarum and Lactobacillus brevis isolates from Brazilian food products. Food Microbiol 36, 22-29.

20. SCAN. 2002. Opinion of the scientific committee on animal nutrition on the criteria for assessing the safety of micro-organisms resistant to antibiotics of human clinical and veterinary importance. European commission, health and consumer protection directorate general; directorate $\mathrm{C}$, scientific opinions, 18 April 2002.

21. Saito, N. and Nei, M. 1987. The neighbor-joining method, a new method for reconstructing phylogenetic trees. Mol Biol Evol 79, 426-434.

22. Sheo, H. J. and Seo, Y. S. 2003. The antibacterial action of Chinese cabbage kimchi juice on Staphylococcus aureus, Salmonella enteritidis and Enterobacter cloacae. J Korean Soc Food Sci Nutr 32, 1351-1356.

23. Shin, K., Chae, O., Park, I., Hong, S. and Choe, T. 1998. Antitumor effects of mice fed with cell lysates of Lactobacillus plantarum isolated from kimchi. Korean Soc Biotechnol Bioeng J 13, 357-363.

24. Sneath, P. H. A. 1986. Endospore-forming gram-positive rods and cocci, pp. 1104-1139. In: Sneath, P. H. A., Mair, N. S., Sharpe, M. E. and Holt, J. G. (eds.), Bergey's manual of systematic Bacteriology. Williams \& Wilkins, Baltimore, Maryland, USA.

25. Thirabunyanon, M., Boonprasom, P. and Niamsup, P. 2009. Probiotic potential of lactic acid bacteria isolated from fermented dairy milks on antiproliferation of colon cancer cells. Biotechnol Lett 31, 571-576.

26. Todorv, S. D. and Dicks, L. M. T. 2008. Evaluation of lactic acid bacteria from kefir, molasses and olive brine as possible probiotics based on physiological properties. Ann Microbiol 58, 661-670.

27. Vrese, M., Stegelmann, A., Ritcher, B., Fenselau, S., Laue, C. and Schrezenmeir, J. 2001. Probiotics: compensation for lactase insufficiency. Am J Clin Nutr 73, S421-S429. 


\section{초록 : 김치로부터 분리된 Lactobacillus strains의 probiotic 특성}

최혜정 ${ }^{1} \cdot$ 임보람 $^{1} \cdot$ 김동완 $^{2} \cdot$ 권기석 ${ }^{3} \cdot$ 주우홍 ${ }^{*}$

('창원대학교 생물학과, ${ }^{2}$ 창원대학교 미생물학과, ${ }^{3}$ 안동대학교 생명자원과학부)

본 연구의 목적은 한국의 전통 발효 식품인 김치로부터 분리된 4 개의 잠재적인 프로바이오틱스 균주의 안전성 과 기능적 특성을 측정하기 위한 것이다. 담즙산염에 대한 높은 내성과 내산성 그리고 소수성 특성에 기초하여 한 균주의 Lactobacillus arizonensis (BCNU 9032)와 3 균주의 L. brevis (BCNU 9037, BCNU 9098 and BCNU 9101) 는 선택되었다. 모든 균주는 $\mathrm{pH} 2.5$ 에서 3 시간 후에도 $99 \%$ 이상 생존가능했고, $1 \%$ 의 담즙산염에 내성을 보였다. 이들 균주는 특히 Echerichia coli와 Shigella sonnei 같은 다수의 식중독 원인균에 대해 우수한 항균활성을 보였다. L. arizonensis BCNU 9032와 L. brevis 9037의 콜레스테롤 수준을 감소시키는 능력은 시험관내 담즙염 가수분해 활성과 콜레스테롤 동화작용 시험을 통해 검증되었다. 게다가, L. brevis BCNU 9098과 BCNU 9101은 Caco-2 cells 에 대해(각각 $12.76,11.86 \%$ ) 상업균주인 Lactobacillus rhamnosus GG 보다 높은 부착능을 가진 것으로 확인되었다. 이러한 결과들을 이들 균주를 프로바이오틱스로서 사용할 수 있음을 제시하고 있다. 